\title{
Arahan Pengembangan Pariwisata di Kawasan Tanjung Lesung Berdasarkan Partisipasi Masyarakat
}

\author{
Fathun Qolbi dan Arwi Yudhi K \\ Departemen Perencanaan Wilayah dan Kota, Fakultas Arsitektur Desain dan Perencanaan, \\ Institut Teknologi Sepuluh Nopember (ITS) \\ e-mail: arwiyudhi@gmail.com
}

\begin{abstract}
Abstrak-Tanjung Lesung merupakan wilayah pesisir yang terletak di Desa Tanjungjaya Kecamatan Panimbang Kabupaten Pandeglang dan sudah lama dikenal sebagai kawasan pariwisata karena memiliki pasir putih dan panorama yang indah, baik di daratan maupun bawah air. Tanjung Lesung telah ditetapkan sebagai KEK Pariwisata berdasarkan Peraturan Pemerintah (PP) Nomor 26 Tahun 2012 tentang Kawasan Ekonomi Khusus Tanjung Lesung, dan semakin menguatkan peran kawasan ini sebagai kawasan pariwisata. Penelitian ini bertujuan untuk merumuskan arahan pengembangan kawasan wisata Tanjung Lesung berbasis partisipasi masyarakat yang ada di kawasan tersebut. Sasaran dalam penelitian ini adalah Identifikasi faktorfaktor berpengaruh dalam Pengembangan Pariwisata Pantai Tanjung Lesung berbasis partisipasi masyarakat menggunakan analisis deskriptif, Mengidentifikasi bentuk-bentuk partisipasi masyarakat dalam pengembangan Pariwisata Pantai Tanjung Lesung menggunakan analisis delphi setelah itu Merumuskan arahan pengembangan Pariwisata Pantai Tanjung Lesung berbasis partisipasi masyarakat dengan teknik analisis deskriptif. Hasil penelitian berupa arahan pengembangan yang tepat dengan melibatkan partisipasi masyarakat yaitu membuka lapangan pekerjaan di sektor pariwisata dari masyarakat sebagai salah satu daya tarik wisata, perbaikan dan peningkatan sarana prasarana yaitu salah satunya masalah persampahan di Tanjung Lesung., membuat tempat pelatihan berupa training center untuk memberikan pendidikan dan pemahaman bagi masyarakat setempat di bidang keterampilan dan keprofesian, dan menjadikan kawasan wisata pantai Tanjung Lesung memiliki tenaga kerja profesional dan kompeten di bidang pariwisata dan kegiatan bisnis.
\end{abstract}

Kata kunci-Kawasan ekonomi khusus, pengembangan pariwisata, partisipasi masyarakat.

\section{PENDAHULUAN}

$\mathrm{T}$ ANJUNG Lesung merupakan wilayah pesisir yang terletak di Desa Tanjungjaya Kecamatan Panimbang Kabupaten Pandeglang dan sudah lama dikenal sebagai kawasan pariwisata karena memiliki pasir putih dan panorama yang indah, baik di daratan maupun bawah air. Hal tersebut dapat terlihat dari sebaran terumbu karang di kawasan ini yang diketahui memiliki luas sekitar 85 hektar [1]. Tanjung Lesung telah ditetapkan sebagai KEK Pariwisata berdasarkan Peraturan Pemerintah (PP) Nomor 26 Tahun 2012 tentang Kawasan Ekonomi Khusus Tanjung Lesung, dan semakin menguatkan peran kawasan ini sebagai kawasan pariwisata. PP tersebut menjelaskan bahwa pengembangan KEK Pariwisata Tanjung Lesung dinilai akan dapat memberikan dampak kepada pertumbuhan ekonomi di wilayah tersebut, baik terhadap berbagai sektor, maupun berbagai kalangan termasuk masyarakat setempat.
Permasalahan yang terjadi adalah masyarakat masih tidak memanfaatkan potensi sumber daya alam yang ada. Desa Tanjungjaya memiliki luas $33 \mathrm{~km}^{2}$ dan memiliki bentang lahan berupa lembah. Penduduk di Desa Tanjungjaya pada tahun 2011 diketahui berjumlah 6.876 jiwa dan terdiri atas 1.826 rumah tangga (2), dan sebagian dari mereka bermukim di wilayah Tanjung Lesung yang akan dikembangkan menjadi KEK Pariwisata. Tanjung Lesung meskipun akan dikembangkan menjadi KEK pariwisata, namun masyarakatnya secara umum memiliki kegiatan di luar sektor pariwisata, seperti sektor perikanan, pertanian, maupun sektor ekonomi lainnya. Wisatawan mengunjungi suatu daerah tujuan wisata antara lain didorong oleh keinginan untuk mengenal, mengetahui, atau mempelajari daerah dan kebudayaan masyarakat lokal. Selama berada di daerah tujuan wisata, wisatawan pasti berinteraksi dengan masyarakat lokal [2]. Penghasilan masyarakat lokal mayoritas bekerja sebagai petani dan nelayan dimana dengan adanya potensi wisata pada kawasan ini tidak muncul sebagai lapangan pekerjaan baru yang akan memanfaatkan untuk masyarakat lokal tersebut.

Pengembangan pariwisata khususnya di Desa Tanjung Jaya Kecamatan Panimbang akan bisa lebih maju dari potensi yang ada pada Kabupaten Pandeglang kalo melibatkan masyarakat, dalam pengembangan pariwisata juga mempertimbangkan wisata laut Biru dan spot snorkling dengan terumbu karang yang masih indah yang masih belum banyak diketahui wisatawan. Berbagai wisata di Tanjung Lesung berperan untuk memberikan kesempatan kerja/ memperkecil pengangguran, dan memberikan efek multiplier dalam perekonomian di sekitar kawasan wisata tersebut. Dengan ditetapkan sebagai KEK Pariwisata berdasarkan Peraturan Pemerintah (PP) Nomor 26 Tahun 2012 tentang Kawasan Ekonomi Khusus Tanjung Lesung perlu ditangkap peluangnya oleh masyarakat yang bergerak di sektor pariwisata.

Maka dari itu rumusan permasalahan penelitian ini adalah potensi wisata yang ada di kawasan Tanjung Lesung cukup besar namun masih belum maksimalnya partisipasi dari masyarakat sekitar kawasan wisata sehingga kegiatannya masih terpisah-pisah dan tidak adanya kerjasama antara pengelola potensi sumber daya alam yang ada dengan masyarakat setempat. Berdasarkan permasalahan tersebut maka tujuan dalam penelitian ini adalah untuk Merumuskan arahan pengembangan kawasan wisata Tanjung Lesung berbasis partisipasi masyarakat. Ruang lingkup penelitian ini yaitu di kawasan Tanjung Lesung yang berada di desa Tanjung Jaya Kecamatan Panimbang Kabupaten Pandeglang. 


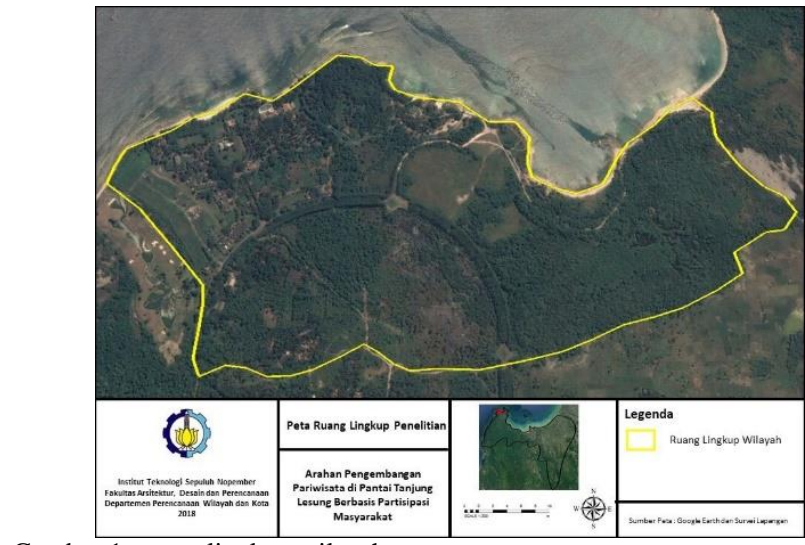

Gambar 1. ruang lingkup wilayah

\section{METODE PENELITIAN}

\section{A. Metode Pengumpulan Data}

Pendekatan yang digunakan adalah pendekatan rasionalistik yaitu proses berpikir yang bertolak dari filsafat rasionalisme, bukan sekedar berfikir menggunakan rasio tetapi berupa pemaknaan empiri dengan memperhatikan nilai-nilai yang ada di kehidupan masyarakat [3]. Dengan begitu, penelitian dengan pendekatan rasionalistik adalah penelitian yang menggunakan akal sebagai patokan dalam menganalisa suatu masalah. Rasionalisme merupakan salah satu aliran filsafat yang membawa kepada kebenaran yang menekankan rasio sebagai sumber utama pengetahuan.

Teknik pengumpulan data primer dilakukan dengan cara observasi dan pengamatan secara langsung dilapangan dengan metode pengamatan dan wawancara. Perolehan data dan informasi dengan cara observasi dilakukan dengan cara pengamatan langsung di pantai tanjung lesung, pengamatan pola kegiatan wisatawan, survey karakteristik masyarakat di sekitar kawasan wisata, dan potensi serta permasalahan yang ada berkaitan dengan pengadaan fasilitas, sarana dan prasarana penunjang wisata dan pemanfaatan ruang, dan seberapa besar keterlibatan masyarakat terhadap kegiatan wisata di kawasan Pantai tanjung lesung.[4]

Metode wawancara dilakukan untuk menyerap pendapat, persepsi atau opini yang subyektif sifatnya. Dalam hal ini metode wawancara yang digunakan menggunakan kuesioner dengan melakukan tanya jawab secara langsung kepada responden, yang dilakukan dalam bentuk pembicaraan yang santai. Kuesioner merupakan daftar pertanyaan atau angket yang berisi pertanyaan yang dilakukan dengan cara menyebarkan kepada responden dengan tujuan untuk mendapatkan informasi, tanggapan, keyakinan, pendapat dan kegiatan respoden terhadap obyek yang ditanyakan. Pemilihan sampel dalam kuisioner ini dilakukan secara sengaja (purposive sampling), baik untuk masyarakat maupun untuk pihak-pihak yang dirasa mewakili obyek penelitian. Demikian pula kuesioner yang ditujukan bagi wisatawan yang mengunjungi kawasan wisata Pantai tanjung lesung.

\section{B. Metode Analisis}

Metode analisis dalam mencapai tujuan penelitian terdiri dari2(dua) tahapan analisis yaitu Identifikasi faktor-faktor yang berpengaruh dalam pengembangan pariwisata di Tanjung Lesung dan mengidentifikasi bentuk-bentuk partisipasi masyarakat dalam pengembangan pariwisata pantai Tanjung Lesung adalah sebagai berikut.

1) Identifikasi faktor-faktor yang berpengaruh dalam pengembangan pariwisata di Tanjung Lesung

Dalam melakukan identifikasi faktor-faktor penentu pengembangan kawasan wisata Tanjung Lesung berbasis partisipasi masyarakat di Desa Tanjung Jaya Kecamatan Panimbang Kabupaten Pandeglang, digunakan metode Analisa Deskriptif karena sangat membantu dalam meringkas perbandingan beberapa variabel data skala dalam satu tabel, dan dapat digunakan untuk melakukan pengamatan apabila adanya penyimpangan data. Metode analisa deskriptif diperlukan dalam menjawab sasaran penelitian yaitu untuk mengidentifikasi faktor-faktor penentu pengembangan kawasan wisata Tanjung Lesung berbasis partisipasi masyarakat di Desa Tanjung Jaya Kecamatan Panimbang.

Dalam analisis ini dilakukan perbandingan antara variabel yang didapat dari kajian pustaka dengan berbagai peraturan perundangan atau pedoman yang berhubungan dengan pengembangan wisata alam, sehingga dapat diketahui faktorfaktor apa saja yang menjadi penentu pengembangan kawasan wisata Tanjung Lesung. Beberapa peraturan perundangan yang digunakan oleh peneliti antara lain UU Nomor 10 Tahun 2010 tentang Kepariwisataan, Permen PU Nomor 47 Tahun 2007 tentang kriteria teknis peruntukan pariwisata untuk jenis wisata alam, dan Peraturan Pemerintah Nomor 28 Tahun 2011 tentang pengelolaan kawasan suaka alam dan kawasan cagar alam. Peraturan tentang pengelolaan suaka alam dan cagar alam diperlukan karena sebagian wilayah penelitian berada di kawasan hutan lindung.

\section{2) Mengidentifikasi bentuk-bentuk partisipasi masyarakat dalam pengembangan pariwisata di pantai Tanjung Lesung}

Untuk mengidentifikasi bentuk-bentuk partisipasi masyarakat dalam pengembangan pariwisata pantai Tanjung Lesung menggunankan teknik analisis Delphi. Analisis Delphi merupakan suatu metode yang dilakukan dengan membentuk suatu kelompok atau komunikasi grup yang terdiri dari para ahli untuk membahas suatu permasalahan merupakan salah satu dari analisis regresi kualitatif.

Umumnya para ahli yang dilibatkan merupakan para ahli yang memiliki keahlian di bidang permasalahan yang sedang dibahas. Para ahli yang ada tidak saling mengetahui siapa saja yang terlibat di dalamnya sampai nantinya dipertemukan pada tahap akhir dari pelaksanaan metode Delphi ini [5].

Tabel 1

Tahap akhir dari pelaksanaan metode Delphi ini

\begin{tabular}{|l|l|}
\hline Variabel & Definisi Operasional \\
\hline & Keberadaan daya tarik wisata \\
- Sumberdaya alam & berwujud sumber daya alam, seperti \\
- Atraksi budaya & karang, atraksi budaya masyarakat \\
& dll yang dapat menarik minat \\
& wisatawan \\
\hline & Kondisi aksesbilitas di luar kawasan \\
- Jalan raya & meliputi transportasi berupa \\
- Transportasi & jaringan jalan dan angkutan masal \\
& menuju kawasan wisata Tanjung \\
& Lesung. \\
\hline
\end{tabular}




\begin{tabular}{|c|c|}
\hline Variabel & Definisi Operasional \\
\hline $\begin{array}{l}\text { - Infrastruktur } \\
\text { - Jaringan utilitas }\end{array}$ & $\begin{array}{l}\text { Ketersediaan infrastruktur pokok } \\
\text { berupa jalan akses di obyek wisata } \\
\text { dan bangunan penunjang kegiatan } \\
\text { wisata; jaringan utilitas pokok } \\
\text { seperti air bersih, listrik, telepon, } \\
\text { persampahan di kawasan untuk } \\
\text { menunjang kegiatan berwisata. }\end{array}$ \\
\hline Kelengkapan sarana/ fasilitas & $\begin{array}{l}\text { Kelengkapan fasilitas penunjang } \\
\text { seperti sarana akomodasi berupa } \\
\text { tempat makan, kamar mandi, } \\
\text { tempat istirahat, tempat ibadah, dll. }\end{array}$ \\
\hline Peningkatan SDM & $\begin{array}{l}\text { Kondisi keahlian SDM meningkat } \\
\text { kualitas pelayanan kegiatan } \\
\text { pariwisata. }\end{array}$ \\
\hline Informasi dan promosi & $\begin{array}{l}\text { Tersedianya sarana informasi dan } \\
\text { usaha promosi guna memasarkan } \\
\text { kawasan wisata Tanjung Lesung } \\
\text { untuk menarik lebih banyak } \\
\text { wisatawan }\end{array}$ \\
\hline Kelestarian lingkungan & $\begin{array}{l}\text { Adanya upaya menjaga kelestarian } \\
\text { lingkungan seperti kebersihan dan } \\
\text { keasrian, jumlah vegetasi, hutan } \\
\text { lindung, dll }\end{array}$ \\
\hline Ide/ pendapat/ rapat & $\begin{array}{l}\text { Adanya partisipasi dalam bentuk } \\
\text { sumbangan ide/pendapat atau saran } \\
\text { dari masyarakat sekitar dalam } \\
\text { membantu pengembangan kawasan } \\
\text { wisata Tanjung Lesung }\end{array}$ \\
\hline $\begin{array}{l}\text { - Perbaikan } \\
\text { - Pembangunan } \\
\text { - Aktivitas sosial }\end{array}$ & $\begin{array}{l}\text { Adanya partisipasi dalam bentuk } \\
\text { bantuan tenaga seperti perbaikan } \\
\text { dan pembangunan } \\
\text { prasarana/fasilitas serta aktivitas } \\
\text { sosial dari masyarakat sekitar dalam } \\
\text { mengembangkan kawasan wisata } \\
\text { Tanjung Lesung }\end{array}$ \\
\hline $\begin{array}{l}\text { - Uang } \\
\text { - Barang } \\
\text { - Penyediaan sarana/fasilitas }\end{array}$ & $\begin{array}{l}\text { Adanya partisipasi dalam bentuk } \\
\text { uang, barang atau penyediaan } \\
\text { sarana/fasilitas dari masyarakat } \\
\text { sekitar untuk membantu } \\
\text { pengembangan kawasan wisata } \\
\text { Tanjung Lesung }\end{array}$ \\
\hline $\begin{array}{l}\text { - Bantuan skill } \\
\text { - Pelatihan }\end{array}$ & $\begin{array}{l}\text { Adanya partisipasi dalam bentuk } \\
\text { bantuan keterampilan atau keahlian } \\
\text { seperti melakukan pelatihan kepada } \\
\text { masyarakat untuk pengembangan } \\
\text { kawasan wisata Tanjung Lesung }\end{array}$ \\
\hline - agen travel ke tanjung lesung & $\begin{array}{l}\text { Keberadaan agen travel ke tanjung } \\
\text { lesung }\end{array}$ \\
\hline
\end{tabular}

\section{ANALISIS DAN PEMBAHASAN}

A. Identifikasi faktor-faktor yang berpengaruh dalam pengembangan pariwisata di Tanjung Lesung.

Dari hasil analisis deskriptif antara variabel penelitian pada kondisi eksisting dengan peraturan perundangan (UU Kepariwisataan No. 10 Tahun 2009, kriteria teknis dari Permen PU No. 41 tahun 2007 dan PP No 28. Tahun 2011 tentang pengelolaan kawasan cagar alam) dan studi terkait peran partisipasi masyarakat dalam pengembangan pariwisata, menunjukkan bahwa variabel yang termasuk sebagai faktorfaktor penentu pengembangan kawasan pariwisata Tanjung Lesung berbasis partisipasi masyarakat adalah keberadaan daya tarik wisata, kondisi prasarana, kelengkapan sarana, peningkatan sumberdaya manusia, kegiatan promosi, dan pelestarian lingkungan. Sementara variabel yang tidak termasuk dalam faktor penentu pengembangan Kawasan Pariwisata Tanjung Lesung berbasis partisipasi masyarakat adalah kondisi aksesbilitas.

Keberadaan daya tarik wisata sebagai faktor penentu yang dimaksudkan meliputi pemanfaatan keberadaan sumberdaya alam dan sumberdaya buatan sebagai daya tarik wisata dalam pengembangan kawasan wisata. Dalam UU No. 10 Tahun 2009 tentang kepariwisataan disebutkan bahwa keberadaan sumberdaya alam dan budaya (buatan) yang potensial sebagai daya tarik wisata dapat dikembangkan sebagai kawasankawasan strategis yang nantinya menjadi keunikan kawasan. Kawasan-kawasan yang potensial dikembangkan sebagai daya tarik wisata di kawasan penelitian antara lain:
a. Obyek wisata Pantai
b. Kawasan terumbu karang
c. Wisata Spot Air
d. Kawasan camping ground
e. Atraksi budaya

Dengan adanya berbagai daya tarik wisata tersebut sebagai sebagai penentu pengembangan kawasan wisata, dapat dikembangkan sebagai suatu instrumen yang bertujuan mempromosikan dan mengembangkan kegiatan usaha yang dilakukan oleh masyarakat. Pemanfaatan yang optimal antara sumberdaya yang ada dan kegiatan-kegiatan usaha masyarakat setempat akan semakin menambah daya tarik kawasan pariwisata Tanjung Lesung, sehingga dapat meningkatkan jumlah wisawatan.

Kondisi prasarana juga merupakan faktor penentu pengembangan kawasan pariwisata Tanjung Lesung berbasis partisipasi masyarakat. Berdasarkan hasil analisa yang telah dilakukan sesuai dengan Permen PU No. 41 Tahun 2007 tentang kriteria teknis pengembangan kawasan wisata alam, menunjukan bahwa kondisi prasarana yang perlu ditingkatkan adalah berupa pelebaran jalan lokal menuju kawasan penelitian, dan pembangunan jaringan listrik yang masih belum tersedia di wana pariwisata Tanjung Lesung. Maka dalam perwujudannya tidak cukup hanya dengan mengandalkan pihak pengelola atau pemerintah daerah, peran partisipasi masyarakat sangat penting agar pengembangan prasarana dapat terealisasi dengan baik.

Faktor penentu pengembangan lainnya adalah kelengkapan sarana penunjang. Berdasarkan hasil analisa pada bagian sebelumnya, sesuai dengan Permen PU No. 41 Tahun 2007 tentang kriteria teknis pengembangan kawasan wisata alam, sarana yang perlu ditingkatkan guna menunjang kegiatan pariwisata di kawasan Tanjung Lesung adalah sarana penginapan. Saat ini telah terdapat wujud partisipasi masyarakat dalam penyediaan jasa penginapan berupa villa/rumah yang berada di sekitar wisata Tanjung Lesung. Selain itu, pengembangan sarana lain yang dapat dilakukan oleh masyarakat adalah dengan pendirian tempat-tempat usaha seperti warung makan atau tempat berjualan oleh-oleh khas daerah setempat.

Pemberdayaan masyarakat juga merupakan faktor penentu pengembangan sebagai bentuk peningkatan sumberdaya manusia. Sesuai yang disebutkan dalam UU No. 10 Tahun 2009 tentang kepariwisataan bahwa pengembangan pariwisata diselenggarakan dengan prinsip untuk memberdayakan masyarakat setempat guna meningkatkan kesejahteraannya. Peningkatan yang dimaksud adalah masyarakat yang berpotensi 
untuk menjadi tenaga kerja harus diberdayakan dengan baik, serta pengembangan wisata mampu menciptakan peluang bisnis atau usaha yang sesuai dengan kemampuan masyarakat setempat. Jika melihat dari wujud partisipasi masyarakat selama ini yang sudah pernah dilakukan dalam membantu pengembangan pariwisata di kawasan penelitian, maka wujud pemberdayaan yang sangat berpeluang untuk dikembangkan adalah adanya pekerjaan dan pengelolaan di bidang penyediaan jasa guide, jasa pemandu, jasa penyediaan penginapan dan berjualan oleh-oleh.

Kegiatan promosi dengan melibatkan partisipasi masyarakat juga merupakan faktor penentu pengembangan kawasan pariwisata Tanjung Lesung. Kegiatan pemasaran yang hanya dilakukan oleh pihak pengelola dan pemerintah daerah, terbukti tidak memberikan dampak yang signifikan dalam meningkatkan jumlah wisatawan. Dari hasil studi penelitian terkait menunjukkan bahwa aktivitas masyarakat dalam kegiatan pariwisata sebenarnya adalah bentuk partisipasi masyarakat dalam upaya mempromosikan wisata di kawasan itu sendiri.

Faktor penentu pengembangan kawasan pariwisata Tanjung Lesung dengan partisipasi masyarakat lainnya adalah dalam upaya menjaga kelestarian lingkungan. Berdasarkan UU No. 10 Tahun 2009 Kepariwisataan dan PP No. 28 Tahun 2011 tentang pengelolaan kawasan cagar alam, disebutkan bahwa pengembangan pariwisata harus bertujuan untuk melestarikan dan melindungi ekosistem, lingkungan dan sumberdaya yang ada. Pengembangan pariwisata berbasis partisipasi masyarakat merupakan strategi yang sangat baik untuk menjaga keseimbangan sumberdaya dan lingkungan hidup. Sehingga diperlukan adanya pengarahan kepada masyarakat akan pentingnya menjaga kelestarian lingkungan dan sumberdaya.

Dari keseluruhan analisis yang dilakukan pada variabelvariabel mengenai faktor-faktor yang menjadi penentu pengembangan kawasan wisata berbasis partisipasi masyarakat, maka dihasilkan enam faktor penentu pengembangan sebagai berikut:

1. Pengembangan dan pemanfaatan berbagai sumberdaya (alam dan buatan) yang menjadi daya tarik kawasan pariwisata Tanjung Lesung sebagai upaya mempromosikan kegiatan-kegiatan usaha yang dilakukan masyarakat sekitar, sehingga memberikan manfaat secara ekonomis.

2. Perbaikan prasarana berupa pelebaran jalan lingkungan yang merupakan jalan akses utama menuju Kawasan Pantai Tanjung Lesung, melalui swadaya masyarakat setempat serta dukungan dari pihak pengelola dan pemerintah daerah.

3. Pengembangan sarana penunjang yang meliputi penambahan fasilitas tempat beristirahat dan penyediaan tempat penginapan, serta pendirian tempat-tempat usaha bagi masyarakat.

4. Pemberdayaan masyarakat setempat melalui suatu bentuk pelatihan untuk meningkatkan keterampilan dan profesi sebagai tenaga kerja di sektor pariwisata, dan menciptakan peluang usaha atau bisnis bagi masyarakat masyarakat yang akan melakukan wirausaha.

5. Peningkatan promosi dan pemasaran kawasan pariwisata Tanjung Lesung melalui kegiatan dan aktivitas yang dilakukan masyarakat sekitar.
Pengarahan kepada masyarakat setempat, baik yang terlibat atau tidak terlibat secara langsung dalam kegiatan pariwisata tentang pentingnya menjaga kelestarian lingkungan dan sumberdaya yang ada di kawasan pariwisata Tanjung Lesung.

\section{B. Mengidentifikasi bentuk-bentuk partisipasi masyarakat dalam pengembangan pariwisata di pantai Tanjung Lesung.}

Identifikasi bentuk bentuk partisipasi masyarakat dalam pengembangan kawasan wisata alam di tanjung lesung Pada tahap ini digunakan analisis delphi untuk mengetahui partisipasi masyarakat dalam bentuk apa saja yang dapat mempengaruhi pengembangan wisata alam di tanjung lesung. Dari beberapa teori yang telah dikaji maka menghasilkan bentuk bentuk partisipasi apa saja yang mempengaruhi pengembangan kawasan kawasan wisata alam di tanjung lesung. Kemudian dilakukan analisis Delphi untuk memvalidasi apakah bentuk-bentuk partisipasi yang telah ditemukan peneliti dapat mempengaruhi pengembangan kawasan wisata alam di tanjung lesung. Wawancara dilakukan kepada beberapa stakeholders terpilih melalui analisis stakeholders. Setelah itu dilakukan wawancara hingga iterasi I untuk mencapai konsensus. Berikut merupakan penjelasan setiap tahapan analisa bentuk bentuk partisipasi yang mempengaruhi pengembangan kawasan wisata alam di tanjung lesung.

1. Tahap identifikasi stakeholders sebagai responden Identifikasi stakeholders didasarkan pada analisis stakeholders berdasarkan tingkat pengaruh dan kepentingan masing - masing stakeholders untuk mengeksplor bentukbentuk partisipasi yang mempengaruhi pengembangan kawasan wisata alam di Tanjung Lesung. Didapatkan 6 responden yaitu Kasubid pariwisata dan kebudayaan, Bappeda Kabupaten Pandeglang, Kasie destinasi wisata alam Dinas Pariwisata dan Kebudayaan Kab Pandeglang, Kasie ekonomi dan pembangunan Kecamatan Pandeglang, Pengelola wisata, masyarakat dan Pengunjung

2. Tahap eksplorasi faktor Pada tahap ini responden memberikan pendapat terhadap masing - masing variabel yang menjadi bentuk-bentuk partisipasi yang mempengaruhi pengembangan kawasan wisata alam di Tanjung Lesung.

Terdapat 10 Variabel yang akan di analisa menggunakan delphi pada tahap eksplorasi kepada para stakeholders. Pada umumnya sebagian besar stakeholders telah memahami dengan baik definisi operasional dari variabel serta memberikan rekomendasi mengenai adanya variabel tambahan maupun koreksi terhadap variabel yang ada.

Tahap Iterasi 1 Setelah melakukan wawancara tahap pertama dapat disimpulkan bahwa terdapat 3 variabel yang masih belum mencapai konsensus. Sehingga perlu dilakukan wawancara ulang untuk mencapai Konsensus. Variabel yang tidak konsensus tersebut, yaitu Partisipasi tenaga dalam bentuk perbaikan, partisipasi harta benda dalam bentuk Barang, dan partisipasi keterampilan dalam bentuk pelatihan berpengaruh terhadap berkembangnya kawasan wisata alam Tanjung Lesung

Hasil akhir analisa delphi yaitu terdapat 7 variabel bentuk bentuk partisipasi masyarakat yang dapat mengembangkan pariwisata di kawasan Tanjung Lesung. 


\section{KESIMPULAN}

Berdasarkan hasil analisa serta pembahasan yang telah dilakukan sebelumnya, maka dapat disimpulkan faktor berpengaruh dalam Pengembangan Pariwisata Pantai Tanjung Lesung berbasis partisipasi masyarakat adalah Keberadaan Daya Tarik Wisata, Aksesibilitas, Prasarana, sarana, Sumber daya manusia, Promosi dan Pemasaran, Serta Pengelolaan Lingkungan. Sedang bentuk partisisipasi yang bisa dilakukan masyarakat untuk ke 6 faktor diatas adalah partisipasi ide pemikiran, tenaga, harta benda dan skill ketrampilan.

\section{UCAPAN TERIMA KASIH}

Penulis mengucapkan banyak terima kasih kepada dosen pembimbing penelitian, Bapak Arwi Yudhi K, ST., MT yang telah banyak sekali memberikan motivasi, saran, dan juga kritik yang membangun demi terselesaikannya penelitian ini dengan baik dan maksimal. Penulis juga mengucapkan terima kasih kepada pihak-pihak terkait yang menjadi sumber dan/atau responden yang membantu mensukseskan penelitian ini.

\section{DAFTAR PUSTAKA}

[1] DKP Kabupaten Pandeglang. 2016.

[2] P. da. Gayatri, "united national converence on travel and tourism," 2005.

[3] Muhadjir, Metodologi Penelitian Kualitatif. Yogyakarta: Rake Sarasin, 2008.

[4] A. Cleosa, "Arahan Pengembangan Kawasan Wisata Pantai Karanggongso dan Pantai Prigi di Kabupaten Trenggalek di Kabupaten Trenggalek," 2017.

[5] Gordon, No Title. 1994. 